\title{
A educação do olho
}

\author{
Francisco Inácio Bastos \\ Pesquisador do Departamento de Informações \\ para a Saúde (CICT/Fiocruz) \\ Av. Brasil, 4365 \\ Rio de Janeiro - RJ Brasil \\ 21040-360
}

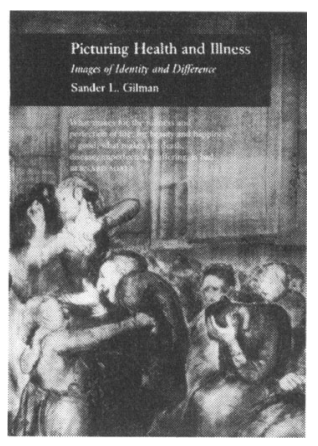

Sander L. Gilman

Picturing bealth and illness: images of identity and difference

Baltimore, Johns

Hopkins University

Press, 1996, 200 p. ander Gilman pertence a um grupo de autores ainda pouco divulgados $\mathcal{O}$ entre nós, que vêm ampliando o círculo de referências no campo das ciências humanas (no nosso caso, em diálogo com a saúde coletiva), a partir de enfoques transdisciplinares, que, mesmo quando não tematizam diretamente assuntos relativos à saúde, têm enriquecido substancialmente o clebate de questões centrais à área, como o conceito de risco (por exemplo, a obra de Ulrich Beck), ou a releitura das relações entre representações simbólicas, cultura e sociedade (como Robert Alter, ou os autores que vêm analisando a questão da "materialidade da comunicação", como H. U. Gumbrecht).

Não me ocorre qualquer paralelo entre a abordagem do autor e pesquisas desenvolvidas entre nós no campo da saúde coletiva e/ou da psicanálise, e talvez a única associação que me vem à lembrança coloca juntos Gilman e a geração de ilustres emigrados que o Brasil teve o privilégio de acolher à época da Segunda Guerra Mundial, nas obras de intelectuais como Otto Maria Carpeaux e Anatol Rosenfeld.

Não constitui tarefa fácil na obra imensa e multifacetada do autor encontrar linhas de força que permitam mapear seu percurso, e, incorrendo antes no risco de parcialidade secundária à ignorância que, em omissão deliberada, diria que seus movimentos situam-se no entroncamento da psicanálise freudiana, da literatura (basicamente alemã e anglo-saxônica, embora o autor demonstre grande familiaridade com as literaturas francesa e italiana), dos estudos judaicos (abrangendo sociologia, história, estudos culturais e folclóricos), além de um profundo conhecimento da história da medicina e das artes visuais, estas duas últimas norteando os ensaios do livro em tela.

Compendiando um imenso repertório de imagens que, como o próprio autor comenta ironicamente, não constitui propriamente sua meta (já que isso, como ele afirma, pode estar facilmente disponibilizado em um CDRom), reconstrói através delas a história das práticas médicas, os contextos culturais das diversas épocas e a imbricação entre conceitos oriundos da ciência e o senso comum. Suas análises surpreendem pelo recurso simultâneo a fontes as mais díspares, e mesmo quando abordam assuntos aparentemente pouco importantes e mesmo esdrúxulos, como uma história dos narizes na literatura e na medicina (pp. 67-92), sempre oferecem ao leitor novos irzsights.

Um dos pontos altos do livro é a discussão acerca da ânsia dos alienistas do século XIX em encontrar uma materialidade do "mental", a ser representada e classificada, como que um suporte "objetivo" a uma nosografia que se quer precisa, e, para Gilman, uma estratégia para "circunscrever" ansiedades acerca de um universo, na verdade, desconhecido (pp. 33-50). Haveria que aflorar no "físico" (especialmente, na expressão fisionômica) a essência do "mal interno" que afligiria o paciente. Estabelecida a correspondência, bastaria 
adestrar o profissional na leitura adequada dos sinais externos, que atingiriam uma materialidade, em tese, tão consistente, a ponto de permitir ao médico alemão August Krauss, em artigo publicado em 1859, equiparar variedades de doença mental a raças eqüinas (??). O próprio título do artigo de Krauss, 'Der Sinn in Wahnsinn' (em um jogo de palavras que se perde na tradução), descreve a busca (para Krauss, a certeza de ter encontrado) do sentido daquilo que (apenas aparentemente, para Krauss) não tem sentido (a loucura/ o delírio).

Subjacente ao livro, define-se uma corrente de interpretação das representações visuais que nos parece ter origem nos filósofos, estetas e críticos alemães do final do século passado e início deste, que tematiza justamente a "intencionalidade histórica da representação espacial" (expressão utilizada por um dos seus estudiosos entre nós, Jorge Lúcio de Campos), e que conta com autores brilhantes como A. Riegl e E. Panofsky, que influenciaram profundamente a compreensão contemporânea das artes visuais. O próprio estilo do autor e seu recurso contínuo ao inglês literário, no que lembra o historiador e psicanalista Peter Gay, parecem reforçar a matriz alemã de sua formação intelectual e, nesta, a vertente culturalista e o diálogo permanente com a história das ciências e das artes.

As "ligaçōes perigosas" entre conceitos (pseudo)científicos e teorias racistas e outras formas de discriminação de minorias, estilos de vida e modos de adoecer são permanentemente denunciadas e "desconstruídas" por Gilman. O eixo deste seu raciocínio é o "desmonte" da equação simplista feiúra-maldade-doença, em oposição à tríade beleza-bondade-saúde. Em combate permanente contra todos os essencialismos tão reconfortantes como pobres e redutores, além de estigmatizantes, o autor não poupa totens culturais como o Nietzsche de $A$ genealogia da moral, que opõe a constituição frágil do judeu a valores supostamente "aristocráticos" (p. 55 do livro de Gilman), ou mesmo o jovem Mark Twain (pp. 93 e ss.), unanimemente conhecido como cronista da tolerância racial. Neste último, ele não contesta a posição aberta e plural (mais clara no escritor maduro), mas sim os seus fundamentos essencialistas e a-históricos.

Gilman situa seus esforços dentro de uma releitura do conceito de mimese (reflexão desenvolvida entre nós por Luiz Costa Lima) não como reflexo imitativo da realidade, mas como inventário criativo e crítico das formas assumidas por esta (introduzindo aí a diferença na suposta identidade). Ele define seu projeto como fruto da modernidade: narrar estórias múltiplas sobre objetos que balizam (e procuram aliviar) as angústias das diversas épocas históricas, comuns e, simultaneamente, distintas.

O olho, nos diz o autor, é o mais racional dos sentidos, e a crônica das representações visuais é também a história da repressão às formas mais imediatamente corporais de percepção do mundo, como o tato, o paladar e o olfato. O próprio Freud incorreria numa supressão da "visceralidade" dos sonhos ao privilegiar, quase exclusivamente, seus aspectos visuais.

A multiplicidade das visões e a devolução de um papel relevante aos outros sentidos caminha, para o autor, na direção oposta à tentadora, porque simplista e reconfortante, visão petrificada e maniqueísta do mundo. A polissemia e o livre fluxo das idéias, diz Gilman, são incômodos porque falam da nossa própria transitoriedade, da fragilidade dos nossos próprios corpos e conceitos. Mas, para Gilman, apostar na simplicidade das demar- 